REVIEW

\title{
Camurati-Engelmann disease: review of the clinical, radiological, and molecular data of 24 families and implications for diagnosis and treatment
}

\author{
$K$ Janssens, $F$ Vanhoenacker, M Bonduelle, L Verbruggen, L Van Maldergem, S Ralston, \\ N Guañabens, N Migone, S Wientroub, M T Divizia, C Bergmann, C Bennett, S Simsek, \\ S Melançon, T Cundy, W Van Hul
}

J Med Genet 2006;43:1-11. doi: 10.1136/jmg.2005.033522

Camurati-Engelmann disease (CED) is a rare autosomal dominant type of bone dysplasia. This review is based on the unpublished and detailed clinical, radiological, and molecular findings in 14 CED families, comprising 41 patients, combined with data from 10 other previously reported CED families. For all 100 cases, molecular evidence for CED was available, as a mutation was detected in TGFB 1 , the gene encoding transforming growth factor (TGF) $\beta 1$. Pain in the extremities was the most common clinical symptom, present in $68 \%$ of the patients. A waddling gait (48\%), easy fatigability $(44 \%)$, and muscle weakness (39\%) were other important features.

Radiological symptoms were not fully penetrant, with $94 \%$ of the patients showing the typical long bone involvement. A large percentage of the patients also showed involvement of the skull (54\%) and pelvis (63\%). The review provides an overview of possible treatments, diagnostic guidelines, and considerations for prenatal testing. The detailed description of such a large set of CED patients will be of value in establishing the correct diagnosis, genetic counselling, and treatment.

See end of article for authors' affiliations

Correspondence to: Prof Dr Wim Van Hul, Department of Medical Genetics, University of Antwerp, Campus Drie Eiken (T6),

Universiteitsplein 1, 2610 Antwerp, Belgium; wim. vanhul@ua.ac.be

Received 1 April 2005 Revised version received 29 April 2005

Accepted for publication 30 April 2005 skull base may be present. The onset of the disease is usually during childhood and almost always before the age of 30. Most patients present with limb pain, muscular weakness, a waddling gait, and easy fatigability. Systemic manifestations-such as anaemia, leucopenia, and hepatosplenomegaly-occur occasionally. ${ }^{6}$ Abnormal values for several markers of bone formation and resorption have been reported in a few patients. ${ }^{78}$

In this review, clinical, radiological, and molecular data on 24 CED families were collected. Presentation of families from Europe, Asia, Africa, America, Australia, and Oceania shows that CED is spread worldwide. Fourteen of the families (4l patients) were examined by at least one of us. Data on 10 additional families (59 patients) were collected from published reports. ${ }^{9-12}$ Including the families presented in this paper, TGFBI mutations in 45 CED families have been described worldwide. ${ }^{10}{ }^{11}{ }^{13-18}$ For the remaining 21 families, however, no published clinical or radiological information was available.

\section{RADIOLOGICAL, SCINTIGRAPHIC, AND CLINICAL MANIFESTATIONS AND PHENOTYPIC VARIABILITY}

Table 1 summarises clinical, radiological, scintigraphic, and molecular data on all the patients. Representative imaging studies and a clinical picture are presented in figs $1-4$. From the data, several important conclusions can be drawn. In $94 \%$ of the patients - defined by the presence of a molecular defect in TGFBI-radiological symptoms are penetrant, with cortical thickening of the diaphyses of the long bones being the first manifestation. The skull (54\%) and pelvis (63\%) are other commonly involved sites. Scintigraphy detected increased osteoblastic activity in the affected regions (limbs, pelvis, skull, spine; see fig 2 ) in $74 \%$ of the investigated patients (17/22). As increased tracer uptake can be perceived even before sclerosis becomes radiologically visible, scintigraphy is a valuable technique for diagnosing CED in an early stage of disease.

Most of the patients also express clinical symptoms $(74 \%)$. The most common symptoms are pain in the extremities $(68 \%)$, a peculiar waddling gait $(48 \%)$, easy fatigability $(44 \%)$, and

Abbreviations: $B M D$, bone mineral density; CED, Camurati-Engelmann disease; TGF, transforming growth factor physes may become affected as well, but epiphyses are spared. ${ }^{5}$ Sclerotic changes at the 
Table 1 Overview of clinical, radiological, scintigraphic, and molecular data on patients from the 24 families

\begin{tabular}{|c|c|c|c|c|c|}
\hline & \multirow{2}{*}{$\frac{\text { Family } 1}{\text { (Belgium) }}$} & \multirow{2}{*}{$\frac{\text { Family } 2}{\text { (Iraq) }}$} & \multirow{2}{*}{$\frac{\text { Family } 3}{\text { (UK) }}$} & \multirow{2}{*}{$\frac{\text { Family } 4}{\text { (Italy) }}$} & \multirow{2}{*}{$\frac{\text { Family } 5}{\text { (Belgium) }}$} \\
\hline & & & & & \\
\hline Mutation (DNA) & $673 \mathrm{~T} \rightarrow \mathrm{C}$ & $653 G \rightarrow A$ & $652 \mathrm{C} \rightarrow \mathrm{T}$ & 28_36dup & $241 \mathrm{~T} \rightarrow \mathrm{C}$ \\
\hline Mutation (protein) & C225R & $\mathrm{R} 218 \mathrm{H}$ & R218C & L10-L12dup & $\mathrm{Y} 81 \mathrm{H}$ \\
\hline Number of patients & 3 & 5 & 3 & 2 & 3 \\
\hline Clinical symptoms & $3 / 3$ & $4 / 5$ & $2 / 3$ & $2 / 2$ & $1 / 3$ \\
\hline Pain in extremities & $2 / 3$ & $4 / 5$ & $2 / 3$ & $0 / 2$ & $1 / 3$ \\
\hline Easy fatigability & $0 / 3$ & $3 / 5$ & $2 / 3$ & $0 / 2$ & $1 / 3$ \\
\hline Muscle weakness & $0 / 3$ & $2 / 5$ & $2 / 3$ & $0 / 2$ & $1 / 3$ \\
\hline Waddling gait & $1 / 3$ & $3 / 5$ & $1 / 3$ & $0 / 2$ & $1 / 3$ \\
\hline Hearing loss & $0 / 3$ & $2 / 5$ & $0 / 3$ & $2 / 2$ & $0 / 3$ \\
\hline Reduced subcutaneous fat & $1 / 3$ & $2 / 5$ & $0 / 3$ & $2 / 2$ & $1 / 3$ \\
\hline Other & Hyperthermia (1/3) & $\begin{array}{l}\text { Hepatosplenomegaly } \\
(1 / 3)\end{array}$ & $\mathrm{ESR}$ and $\mathrm{CRP} \uparrow(2 / 3)$ & - & Small stature $(1 / 3)$ \\
\hline & & $\begin{array}{l}\text { Cranial nerve } \\
\text { compression (1/3) }\end{array}$ & & & \\
\hline & & Small stature $(2 / 3)$ & & & \\
\hline & & Headache $(1 / 3)$ & & & \\
\hline Radiological abnormalities & $3 / 3$ & $5 / 5$ & $3 / 3$ & $2 / 2$ & $1 / 3$ \\
\hline Cortical thickening diaphyses & $3 / 3$ & $5 / 5$ & $3 / 3$ & $2 / 2$ & $1 / 3$ \\
\hline Sclerosis of skull & $1 / 3$ & $2 / 5$ & ND & $2 / 2$ & $0 / 3$ \\
\hline Other & - & - & $\begin{array}{l}\text { Spine osteoporotic } \\
(2 / 3)\end{array}$ & Spine, pelvis $(1 / 2)$ & - \\
\hline & & & Coxa valga $(2 / 3)$ & & \\
\hline Increased BMD & ND & ND & $\begin{array}{l}+ \text { (hip) }(2 / 3) \\
- \text { (spine) }(2 / 3)\end{array}$ & $2 / 2$ & ND \\
\hline Scintigraphic abnormalities & ND & $4 / 4$ & ND & $1 / 1$ & $1 / 1$ \\
\hline \multirow[t]{7}{*}{ Treatment } & GC (1/3) & GC (1/5) & GC (2/3) & Calcitonin (1/2) & $G C(1 / 3)$ \\
\hline & NSAIDs (1/3) & & NSAIDs $(2 / 3)$ & $\mathrm{BP}(2 / 2)$ & NSAIDs (1/3) \\
\hline & & & $\begin{array}{l}\text { Analgesics (2/3) } \\
\operatorname{BP}(2 / 3)\end{array}$ & & Analgesics (1/3) \\
\hline & & & Tibial osteotomy (1/3) & & \\
\hline & & & $\begin{array}{l}\text { Femoral osteotomy } \\
(1 / 3)\end{array}$ & & \\
\hline & Family 6 & Family 7 & Family 8 & Family 9 & Family 10 \\
\hline & (Belgium) & (Italy) & (Germany) & (UK) & (Tonga-Oceania) \\
\hline Mutation (DNA) & $241 \mathrm{~T} \rightarrow \mathrm{C}$ & $653 \mathrm{G} \rightarrow \mathrm{A}$ & $653 G \rightarrow A$ & $653 G \rightarrow A$ & $653 G \rightarrow A$ \\
\hline Mutation (protein) & Y81H & $\mathrm{R} 218 \mathrm{H}$ & $\mathrm{R} 218 \mathrm{H}$ & $\mathrm{R} 218 \mathrm{H}$ & $\mathrm{R} 218 \mathrm{H}$ \\
\hline Number of patients & 6 & 2 & 3 & 2 & 2 \\
\hline Clinical symptoms & $3 / 6$ & $2 / 2$ & $1 / 3$ & $1 / 2$ & $1 / 2$ \\
\hline Pain in extremities & $2 / 6$ & $1 / 2$ & $1 / 3$ & $1 / 2$ & $0 / 2$ \\
\hline Easy fatigability & $1 / 6$ & $1 / 2$ & $1 / 3$ & $0 / 2$ & $0 / 2$ \\
\hline Muscle weakness & $1 / 6$ & $1 / 2$ & $1 / 3$ & $0 / 2$ & $0 / 2$ \\
\hline Waddling gait & $2 / 6$ & $2 / 2$ & $1 / 3$ & $0 / 2$ & $0 / 2$ \\
\hline Hearing loss & $0 / 6$ & $0 / 2$ & $0 / 3$ & $0 / 2$ & $1 / 2$ \\
\hline Reduced subcutaneous fat & $0 / 6$ & $1 / 2$ & $0 / 3$ & $0 / 2$ & $0 / 2$ \\
\hline Other & - & - & - & - & Proptosis (1/2) \\
\hline Radiological abnormalities & $4 / 6$ & $2 / 2$ & $1 / 1$ & $2 / 2$ & $2 / 2$ \\
\hline Cortical thickening diaphyses & $4 / 6$ & $2 / 2$ & $1 / 1$ & $2 / 2$ & $2 / 2$ \\
\hline Sclerosis of skull & $1 / 2$ & $0 / 2$ & ND & ND & $1 / 1$ \\
\hline Other & Pelvis (1/2) & - & - & ND & - \\
\hline Increased BMD & ND & ND & ND & ND & $1 / 1$ \\
\hline Scintigraphic abnormalities & $1 / 6$ & ND & $1 / 1$ & ND & $1 / 1$ \\
\hline \multirow[t]{5}{*}{ Treatment } & $G C(1 / 6)$ & - & Penicillin & Treated with & Orbital \\
\hline & $\operatorname{BP}(1 / 6)$ & & Gold salts & vitamin D for & decompression (1/1) \\
\hline & & & NSAIDs & $\begin{array}{l}\text { presumed rickets } \\
(1 / 2)\end{array}$ & \\
\hline & Family 11 & Family 12 & Family 13 & Family 14 & Family $15^{\star}$ \\
\hline & (Morocco) & (Belgium) & (Spain) & (Germany) & (Israel) \\
\hline Mutation (DNA) & $463 C \rightarrow T$ & $673 \mathrm{~T} \rightarrow \mathrm{C}$ & $652 \mathrm{C} \rightarrow \mathrm{T}$ & $664 C \rightarrow G$ & $652 \mathrm{C} \rightarrow \mathrm{T}$ \\
\hline Mutation (protein) & $\mathrm{R} 156 \mathrm{C}$ & C225R & R218C & $H 222 D$ & R218C \\
\hline Number of patients & 2 & 3 & 4 & 1 & 16 \\
\hline Clinical symptoms & $2 / 2$ & $2 / 3$ & $4 / 4$ & $1 / 1$ & $10 / 16$ \\
\hline Pain in extremities & $2 / 2$ & $2 / 3$ & $2 / 4$ & $1 / 1$ & $8 / 8$ \\
\hline Easy fatigability & $1 / 2$ & $1 / 3$ & $0 / 4$ & $1 / 1$ & ND \\
\hline
\end{tabular}




\begin{tabular}{|c|c|c|c|c|c|}
\hline & Family 11 & Family 12 & Family 13 & Family 14 & Family $15^{*}$ \\
\hline & (Morocco) & (Belgium) & (Spain) & (Germany) & (Israel) \\
\hline $\begin{array}{l}\text { Muscle weakness } \\
\text { Waddling gait } \\
\text { Hearing loss } \\
\text { Reduced subcutaneous fat } \\
\text { Other }\end{array}$ & $\begin{array}{l}0 / 2 \\
1 / 2 \\
0 / 2 \\
\text { Obese (2/2) } \\
\text { ESR and CRP } \uparrow \\
(1 / 2)\end{array}$ & $\begin{array}{l}1 / 3 \\
1 / 3 \\
0 / 3 \\
\text { Obese }(1 / 3) \\
-\end{array}$ & $\begin{array}{l}/ 4 \\
1 / 4 \\
0 / 4 \\
0 / 4 \\
\text { Vision } \downarrow(1 / 4) \\
\text { Mild splenomegaly (2/4) } \\
\text { Recurrent facial } \\
\text { paralysis }(1 / 4) \\
\text { Hypertension }(1 / 4)\end{array}$ & $\begin{array}{l}1 / 1 \\
1 / 1 \\
0 / 1 \\
1 / 1 \\
\text { Delayed puberty } \\
\text { Small stature }\end{array}$ & $\begin{array}{l}4 / 8 \\
6 / 8 \\
0 / 8 \\
\text { ND } \\
\text { Inability to run quickly } \\
(3 / 8)\end{array}$ \\
\hline $\begin{array}{l}\text { Radiological abnormalities } \\
\text { Cortical thickening diaphyses } \\
\text { Sclerosis of skull } \\
\text { Other }\end{array}$ & $\begin{array}{l}2 / 2 \\
2 / 2 \\
0 / 2 \\
\text { Enlarged mandible } \\
(1 / 2)\end{array}$ & $\begin{array}{l}3 / 3 \\
3 / 3 \\
0 / 3 \\
\text { Kyphoscoliosis }(1 / 3) \\
\text { Coxa valga }(1 / 3)\end{array}$ & $\begin{array}{l}4 / 4 \\
4 / 4 \\
4 / 4 \\
\text { Pelvis }(3 / 4) \\
\text { Spine }(1 / 4) \\
\text { Vertebrae }(1 / 4)\end{array}$ & $\begin{array}{l}1 / 1 \\
1 / 1 \\
0 / 1 \\
\text { Genu valgum } \\
\text { Pes valgus } \\
\text { Coxa valga }\end{array}$ & $\begin{array}{l}11 / 11 \\
11 / 11 \\
\text { ND } \\
\text { ND }\end{array}$ \\
\hline Increased BMD & ND & ND & ND & ND & ND \\
\hline Scintigraphic abnormalities & $2 / 2$ & $1 / 2$ & $4 / 4$ & ND & ND \\
\hline \multirow[t]{3}{*}{ Treatment } & $\begin{array}{l}\text { Analgesics (2/2) } \\
\text { GC (2/2) }\end{array}$ & NSAIDs (2/3) & $G C(1 / 4)$ & - & $?$ \\
\hline & Family 16† & Family $17 \ddagger$ & Family $18 \ddagger$ & Family $19 \ddagger$ & Family $20 \ddagger$ \\
\hline & (Japan) & (Portugal) & (France) & (Belgium) & (France) \\
\hline $\begin{array}{l}\text { Mutation (DNA) } \\
\text { Mutation (protein) } \\
\text { Number of patients }\end{array}$ & $\begin{array}{l}673 \mathrm{~T} \rightarrow \mathrm{C} \\
\mathrm{C} 225 \mathrm{R} \\
12\end{array}$ & $\begin{array}{l}653 \mathrm{G} \rightarrow \mathrm{A} \\
\mathrm{R} 218 \mathrm{H} \\
12\end{array}$ & $\begin{array}{l}652 C \rightarrow T \\
R 218 C \\
2\end{array}$ & $\begin{array}{l}673 \mathrm{~T} \rightarrow \mathrm{C} \\
\mathrm{C} 225 \mathrm{R} \\
3\end{array}$ & $\begin{array}{l}\text { 673T } \rightarrow C \\
C 225 R \\
3\end{array}$ \\
\hline $\begin{array}{l}\text { Clinical symptoms } \\
\text { Pain in extremities } \\
\text { Easy fatigability } \\
\text { Muscle weakness } \\
\text { Waddling gait } \\
\text { Hearing loss } \\
\text { Reduced subcutaneous fat } \\
\text { Other }\end{array}$ & $\begin{array}{l}10 / 12 \\
10 / 12 \\
N D \\
7 / 12 \\
5 / 12 \\
3 / 12 \\
\text { ND } \\
\text { Marfanoid habitus } \\
\text { (3/12) } \\
\text { Facial nerve palsy } \\
(1 / 12) \\
\text { Delayed puberty } \\
(1 / 1)\end{array}$ & $\begin{array}{l}10 / 12 \\
10 / 12 \\
8 / 12 \\
7 / 12 \\
7 / 12 \\
\text { ND } \\
\text { ND } \\
\text { Headache }(2 / 12) \\
\text { Poor appetite (2/12) } \\
\text { Delayed puberty (?) }\end{array}$ & $\begin{array}{l}2 / 2 \\
2 / 2 \\
1 / 2 \\
1 / 2 \\
1 / 1 \\
\text { ND } \\
\text { ND } \\
\text { Poor appetite }(1 / 2)\end{array}$ & $\begin{array}{l}2 / 3 \\
2 / 3 \\
2 / 3 \\
2 / 3 \\
1 / 3 \\
\text { ND } \\
\text { ND }\end{array}$ & $\begin{array}{l}2 / 3 \\
2 / 3 \\
2 / 3 \\
2 / 3 \\
2 / 3 \\
\text { ND } \\
\text { ND } \\
\text { Headache }(3 / 3) \\
\text { Poor appetite }(1 / 3)\end{array}$ \\
\hline $\begin{array}{l}\text { Radiological abnormalities } \\
\text { Cortical thickening diaphyses } \\
\text { Sclerosis of skull } \\
\text { Other }\end{array}$ & $\begin{array}{l}12 / 12 \\
12 / 12 \\
3 / 12 \\
\text { ND }\end{array}$ & $\begin{array}{l}10 / 10 \\
10 / 10 \\
9 / 11 \\
\text { ND }\end{array}$ & $\begin{array}{l}N D \\
N D \\
N D \\
N D\end{array}$ & $\begin{array}{l}3 / 3 \\
3 / 3 \\
\text { ND } \\
\text { ND }\end{array}$ & $\begin{array}{l}3 / 3 \\
3 / 3 \\
1 / 2 \\
\text { ND }\end{array}$ \\
\hline Increased BMD & ND & $8 / 10$ & $2 / 2$ & $3 / 3$ & $3 / 3$ \\
\hline Scintigraphic abnormalities & $1 / 1$ & ND & ND & ND & ND \\
\hline \multirow[t]{3}{*}{ Treatment } & $?$ & $\mathrm{GC}(1 / 12)$ & $?$ & $?$ & $?$ \\
\hline & Family $21 \ddagger$ & Family 22ł & Family 23‡ & Family $24 \S$ & \\
\hline & (Australia) & (France) & (France) & $\overline{\text { (USA) }}$ & Summary \\
\hline $\begin{array}{l}\text { Mutation (DNA) } \\
\text { Mutation (protein) } \\
\text { Number of patients }\end{array}$ & $\begin{array}{l}673 \mathrm{~T} \rightarrow \mathrm{C} \\
\mathrm{C} 225 \mathrm{R} \\
2\end{array}$ & $\begin{array}{l}652 \mathrm{C} \rightarrow \mathrm{T} \\
\mathrm{R} 218 \mathrm{C} \\
1\end{array}$ & $\begin{array}{l}652 C \rightarrow T \\
R 218 C \\
2\end{array}$ & $\begin{array}{l}653 \mathrm{G} \rightarrow \mathrm{A} \\
\mathrm{R} 218 \mathrm{H} \\
6\end{array}$ & 100 \\
\hline $\begin{array}{l}\text { Clinical symptoms } \\
\text { Pain in extremities } \\
\text { Easy fatigability } \\
\text { Muscle weakness } \\
\text { Waddling gait } \\
\text { Hearing loss } \\
\text { Reduced subcutaneous fat }\end{array}$ & $\begin{array}{l}2 / 2 \\
2 / 2 \\
2 / 2 \\
1 / 2 \\
1 / 2 \\
\text { ND } \\
\text { ND }\end{array}$ & $\begin{array}{l}1 / 1 \\
1 / 1 \\
1 / 1 \\
1 / 1 \\
1 / 1 \\
\text { ND } \\
\text { ND }\end{array}$ & $\begin{array}{l}2 / 2 \\
2 / 2 \\
1 / 2 \\
1 / 2 \\
1 / 2 \\
\text { ND } \\
\text { ND }\end{array}$ & $\begin{array}{l}4 / 6 \\
3 / 6 \\
3 / 6 \\
4 / 6 \\
4 / 6 \\
2 / 6 \\
2 / 6\end{array}$ & $\begin{array}{l}74 / 100(74 \%) \\
63 / 92(68 \%) \\
32 / 72(44 \%) \\
36 / 92(39 \%) \\
44 / 92(48 \%) \\
10 / 67(15 \%) \\
10 / 47(21 \%)-3 / 47 \\
16 \%) \text { obese }\end{array}$ \\
\hline Other & $\begin{array}{l}\text { Headache }(2 / 2) \\
\text { Poor appetite }(2 / 2)\end{array}$ & Poor appetite & $\begin{array}{l}\text { Headache }(1 / 2) \\
\text { Poor appetite }(1 / 2)\end{array}$ & $\begin{array}{l}\text { Vertigo, tinnitus, } \\
\text { balance problems } \\
(2 / 6) \\
\text { Delayed puberty } 1 / 6\end{array}$ & \\
\hline
\end{tabular}




\begin{tabular}{|c|c|c|c|c|c|}
\hline & Family $21 \ddagger$ & Family 22 & Family $23 \ddagger$ & Family $24 \S$ & \\
\hline & (Australia) & (France) & (France) & (USA) & Summary \\
\hline & & & & $\begin{array}{l}\text { Poor appetite }(1 / 6) \\
\text { Facial paralysis }(1 / 6\end{array}$ & \\
\hline $\begin{array}{l}\text { Radiological abnormalities } \\
\text { Cortical thickening diaphyses } \\
\text { Sclerosis of skull } \\
\text { Other }\end{array}$ & $\begin{array}{l}2 / 2 \\
2 / 2 \\
2 / 2 \\
N D\end{array}$ & $\begin{array}{l}1 / 1 \\
1 / 1 \\
1 / 1 \\
\text { ND }\end{array}$ & $\begin{array}{l}2 / 2 \\
2 / 2 \\
2 / 2 \\
\text { ND }\end{array}$ & $\begin{array}{l}3 / 4 \\
3 / 4 \\
3 / 4 \\
\text { Enlarged mandible } \\
(1 / 6) \\
\text { Genu valgum }(3 / 6) \\
\text { Pes planus }(3 / 6)\end{array}$ & $\begin{array}{l}82 / 87(94 \%) \\
82 / 87(94 \%) \\
32 / 59(54 \%) \\
\text { Pelvis } 5 / 8(63 \%)\end{array}$ \\
\hline Increased BMD & $2 / 2$ & $1 / 1$ & $2 / 2$ & ND & $26 / 29(90 \%)$ \\
\hline Scintigraphic abnormalities & ND & ND & ND & ND & $17 / 23(74 \%)$ \\
\hline Treatment & $?$ & $?$ & $?$ & $\begin{array}{l}\mathrm{GC}(2 / 6) \\
\text { Hip surface } \\
\text { replacement }(1 / 6) \\
\text { Tibial, fibular, and } \\
\text { femoral osteotomy } \\
(1 / 6)\end{array}$ & \\
\hline \multicolumn{6}{|c|}{$\begin{array}{l}\text { *This family has been described by Janssens et al. } .^{12} \\
\text { †This family has been described by Makita et al." } \\
\text { †These families have been described by Campos-Xavier et al. }{ }^{10} \\
\text { SThis family has been described by Wallace et al." } \\
\text { ?, Data not available; - data absent; } \uparrow \text {, increased; } \downarrow \text {, decreased. } \\
\text { BMD, bone mineral density; BP, bisphophonates; CRP, C reactive protein; ESR, erythrocyte sedimentation rate; GC, glucocorticoids; ND, not determined; NSAIDs, } \\
\text { non-steroidal anti-inflammatory drugs. }\end{array}$} \\
\hline
\end{tabular}

muscle weakness (39\%). Reduced subcutaneous fat $(21 \%)$ and hearing loss $(15 \%)$ are less common.

The extreme variability in phenotypical expression, both between families sharing the same mutation and among members of the same family, makes it difficult to detect possible genotype-phenotype correlations. Irrespective of the nature of the mutation, the age of onset and disease progression appear highly unpredictable. As previously observed by others, ${ }^{5}{ }^{19}$ there seems to be a tendency for an earlier age of onset or a more severe phenotype, or both, in successive generations, a phenomenon known as anticipation. A trend towards increased severity in successive generations was observed in at least seven families. However, in five of these families, diagnosis in the asymptomatic parent was made after giving birth to a severely affected child, creating the appearance of anticipation. Additionally, there was amelioration of disease outcome in successive generations in two families. Furthermore, the nature of the mutations is not in favour of anticipation. The Leu repeat expansion in family 4 forms an exception, but 60 Italian control individuals did not show evidence of instability in this repeat. It seems more plausible that additional genetic factors (for example, single nucleotide polymorphisms (SNPs) in TGFBI or other genes) modulate the outcome of the principal mutation. A study by CamposXavier et $a l^{10}$ detected no association between the promoter SNPs C-509T and C-800T or the coding SNPs T29C and G75C and disease severity in families 17 to 23. Likewise, no association was found between the same four and four additional TGFBI polymorphisms and disease outcome in family $24 .{ }^{11}$ These results suggest that genes different from TGFB1 might influence the disease outcome.

\section{MOLECULAR ANALYSIS AND PATHOGENESIS}

Mutation analysis in 46 CED families ${ }^{10}{ }^{11}{ }^{13-18} 20$ identified 10 different mutations in the TGFBI gene in all but one family (table 2; fig 5). The absence of a mutation in a family described by Hecht et al ${ }^{15}$ raises the possibility of genetic heterogeneity in this disorder. This is further suggested by the absence of mutations in the coding region of TGFBI in several isolated patients and small families investigated in our laboratory (unpublished data). However, the disease in the latter families might be caused by a mutation in a noncoding position of TGFBI, affecting, for example, mRNA stability, protein expression level, or transcription factor binding. The possibility that CED is not the underlying disorder in these families should also not be overlooked: in a substantial subset of our patients lacking a TGFBI mutation, we found indications that the diagnosis was incorrect (either because they had atypical radiological, clinical, or biochemical findings, or because of a different inheritance pattern). Thus far, we have not been able to find convincing evidence for genetic heterogeneity in our set of cases and families.

Transforming growth factor $\beta 1$ (TGF $\beta 1$ ) is formed as a proprecursor molecule, consisting of the signal peptide, the latency associated peptide, and the mature peptide. Posttranslational processing yields the small latent complex, a non-covalent association between two latency associated peptides and two mature peptides. The majority $(7 / 10)$ of the mutations detected in CED are missense mutations located in exon 4, coding for the region in the latency associated peptide surrounding the residues responsible for homodimerisation (Cys223 and Cys225)-making up 82.2\% of all mutations reported so far. The arginine residue at position 218 is a mutation hotspot, representing $60 \%$ of the mutations. Mutations outside exon 4 include a nine base pair duplication in the part of exon 1 encoding the signal peptide, and two missense mutations in exon 1 and exon 2 at the $\mathrm{N}$-terminus of the latency associated peptide.

Functionally, the CED mutations have been classified into two groups. ${ }^{17}$ Exon 4 mutations destabilise disulphide bridging of the latency associated peptides, causing premature activation of the mature peptide. Exon 1 mutations rather affect secretion, leading to intracellular retention of the mutant protein. All mutations investigated so far increase TGF $\beta 1$ activity. ${ }^{172}$ In CED patients, the narrowing of the 

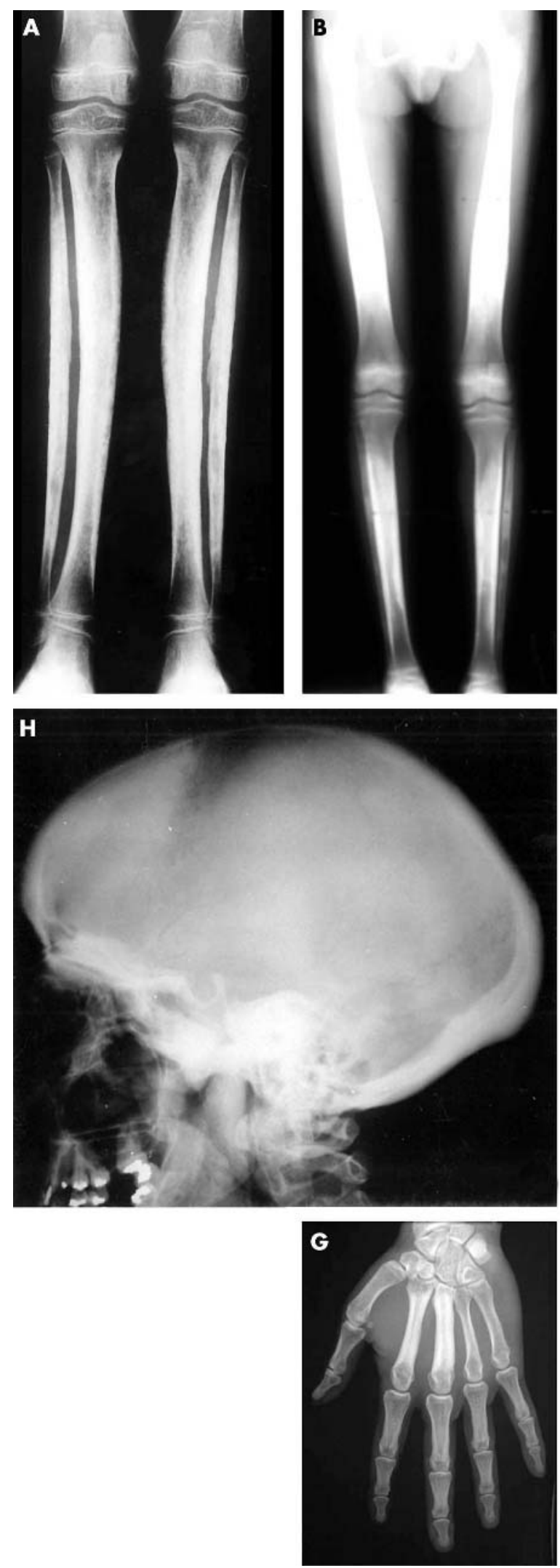
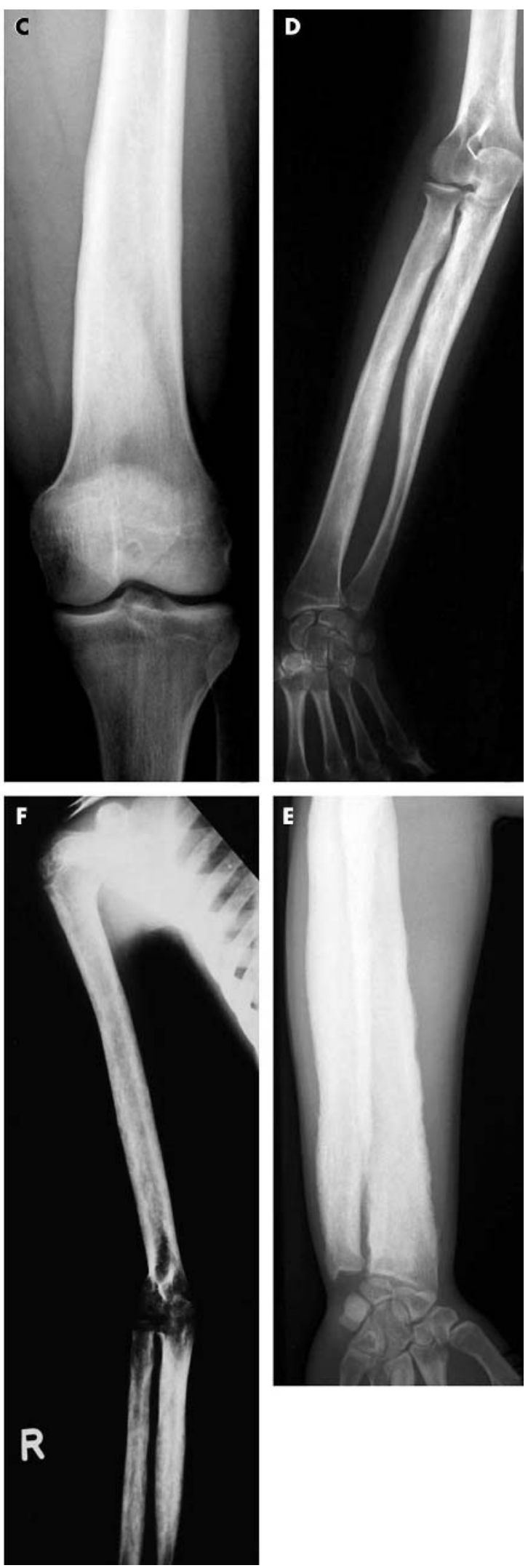

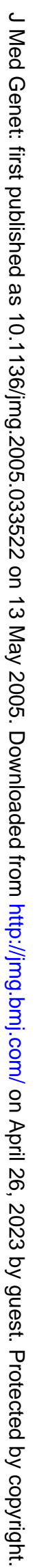

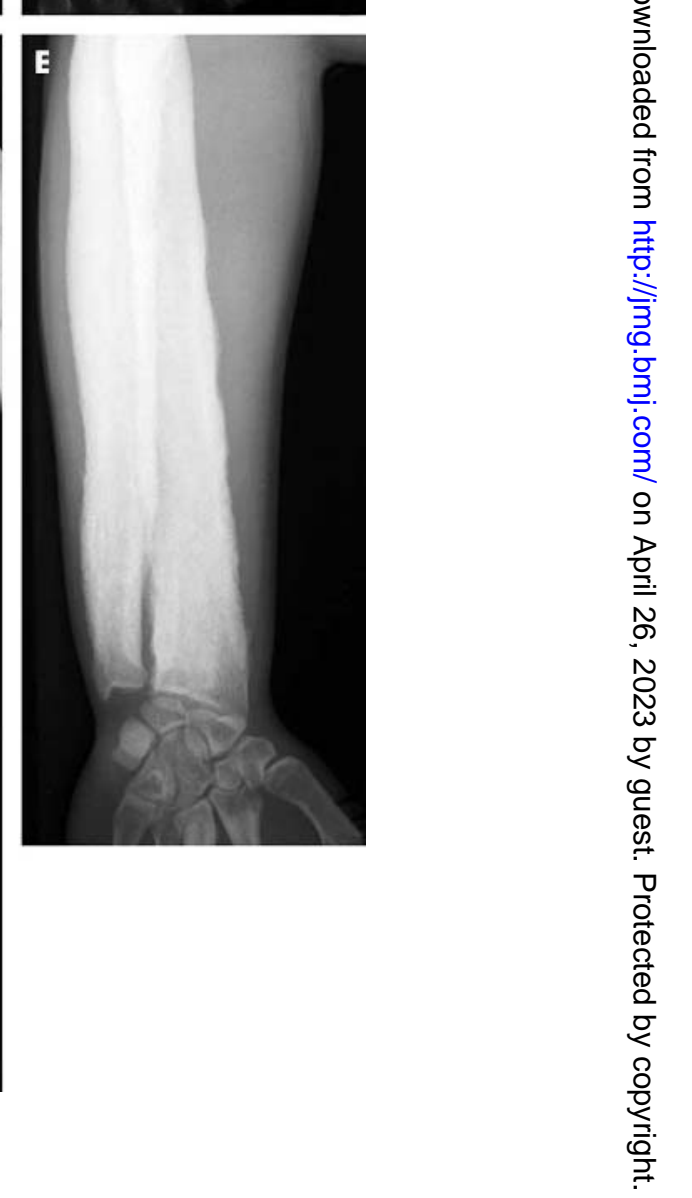




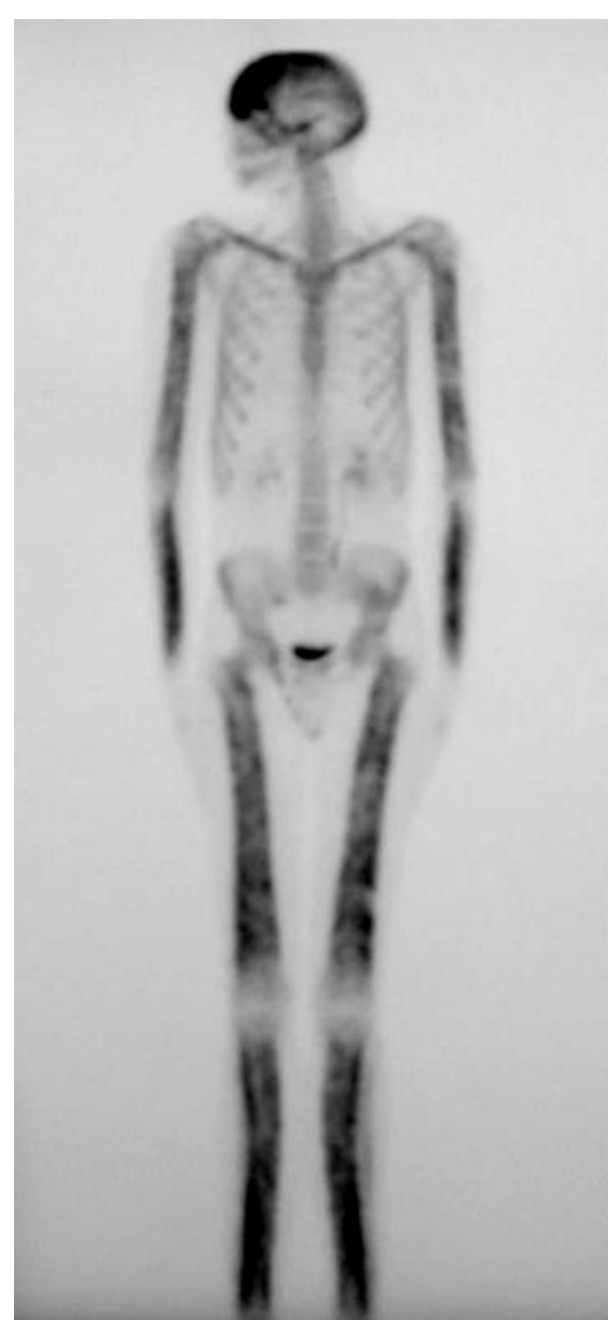

Figure 2 Whole body bone scintigraphy of a patient from family 13 showing the symmetrical distribution of the disease. Increased tracer uptake is visible in the diaphyseal portion of the long bones of the femora, lower legs, humeri and forearms, clavicles, and frontal bones. There is minor increased uptake at the parietal and occipital bones. Also note the slight valgus deformity of the knees.

medullary cavity at the endosteal side and the modelling defect at the periosteal side of the diaphyses of the long bones suggest that the osteoclastic resorption capacity and the osteoblastic bone formation are both disturbed. This observation is in line with the presumed action of the mutant protein, as TGF $\beta 1$ has been shown to stimulate bone formation and suppress bone resorption under physiological conditions. ${ }^{22}$

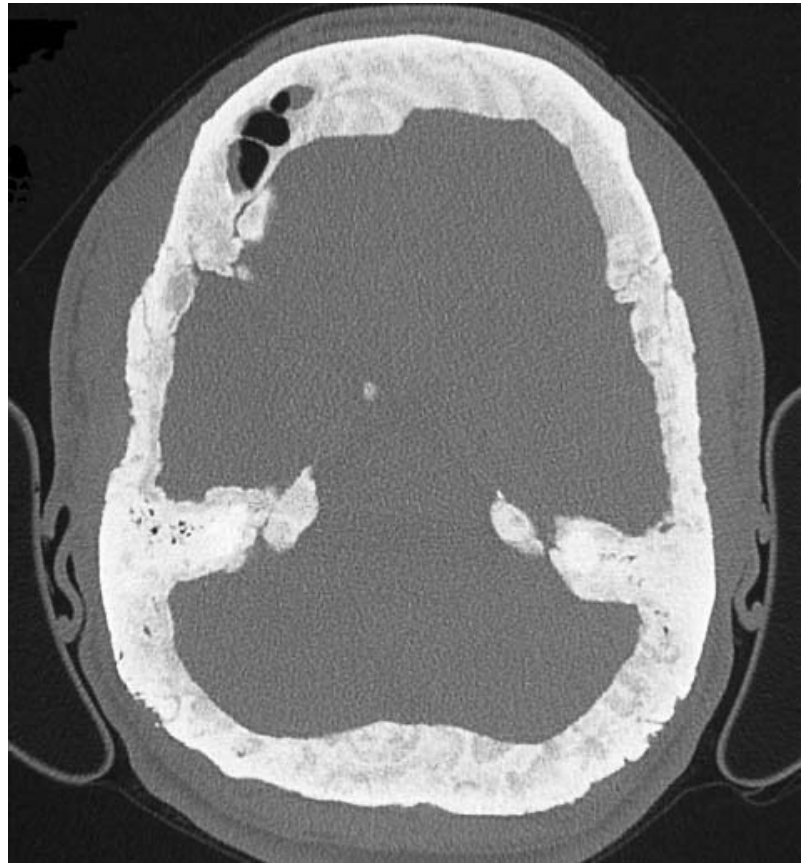

Figure 3 Axial computed tomography (bone window) of the head of a patient from family 10 , showing extensive sclerosis and thickening at the calvaria and petrous bones with loss of the diploe. Note also obliteration of the left frontal sinus.

Most clinical features of CED-such as bone pain in the limbs, waddling gait, and auditory impairment-are secondary to the hyperostosis and sclerosis of the skeleton. However, the reduction in fat and muscle mass, observed in a significant percentage of the patients $(21 \%$ and $39 \%$, respectively, in this population), seems to be unrelated to the affection of the skeleton. We sought to clarify these additional symptoms on the basis of the mutations detected. TGF $\beta 1$ is a known inhibitor of myogenesis, impairing fusion of myoblasts into multinucleated myotubes. ${ }^{23}$ Indeed, recent evidence points to a role for the TGF $\beta$ pathway in repressing the expression of two important myogenic transcription factors. ${ }^{24}$ TGF $\beta 1$ also inhibits adipogenesis, ${ }^{25}$ at least partly through the transcriptional repression of genes important in adipocyte differentiation. ${ }^{26}$ Increased TGF $\beta 1$ activity, as seen in CED patients, is therefore expected to inhibit muscle and fat development. It is of note that dexamethasone, a synthetic glucocorticoid and a known stimulator of adipogenesis, was recently shown to reverse TGF $\beta$ mediated inhibition of preadipocyte differentiation. ${ }^{27}$

How can it be explained that activating mutations in a protein like TGF $\beta 1$, whose receptors are ubiquitously expressed, ${ }^{28}$ cause the relatively mild CED phenotype? One

Figure 1 Typical radiographs of CED patients from different families. (A) AP radiographs of both lower legs of a patient from family 14. There is cortical thickening and severe modelling defect at the diaphysis of both tibiae and fibulae. (B) Full leg radiograph (AP view) of a patient from family 2. Note the cortical sclerosis and the modelling defect with symmetrical distribution at the diaphyses of the femora, tibiae, and fibulae, with sparing of the metaphyses and epiphyses. (C) Radiograph of the left distal femur (AP view) of a patient from family 11. Cortical thickening at the diaphysis of the femur-especially at the medial aspect-results in a modelling defect. Note sparing of the metaphysis and epiphysis. (D) Plain radiograph of the right forearm (AP view) from a patient from family 5. Cortical sclerosis and modelling defect can be seen at both radius and ulna, but are most striking at the proximal diaphysis of the ulna. (E) Standard radiograph of the forearm of a patient from family 10. Marked cortical thickening at the diaphysis of the ulna and radius can be observed, causing obliteration of the medullary cavity and hypertrophy of the long bones. Note extension of the cortical sclerosis towards the distal metaphysis of the radius. (F) Radiograph of the right arm (AP view) of a patient from family 14. Thickening of the cortex of the diaphyseal portion of the humerus, ulna, and radius is present, resulting in narrowing of the medullary canal. Note also the modelling defect of the long bones, which is most extensive at the diaphysis of the ulna. (G) Radiograph of the left hand (AP view) of a patient from family 10, showing cortical sclerosis, cortical thickening, and medullary cavity obliteration at the diaphysis of metacarpals 2 and 3. (H) Radiograph of the skull (lateral view) of a patient from family 1. Sclerosis of the calvaria, the tympanic portion of the skull base, and the ascending ramus of the mandible is visible. Note relatively small frontal and sphenoidal sinuses resulting from adjacent sclerosis of the frontal bone and upper part of the face. The maxillary sinuses are spared. 


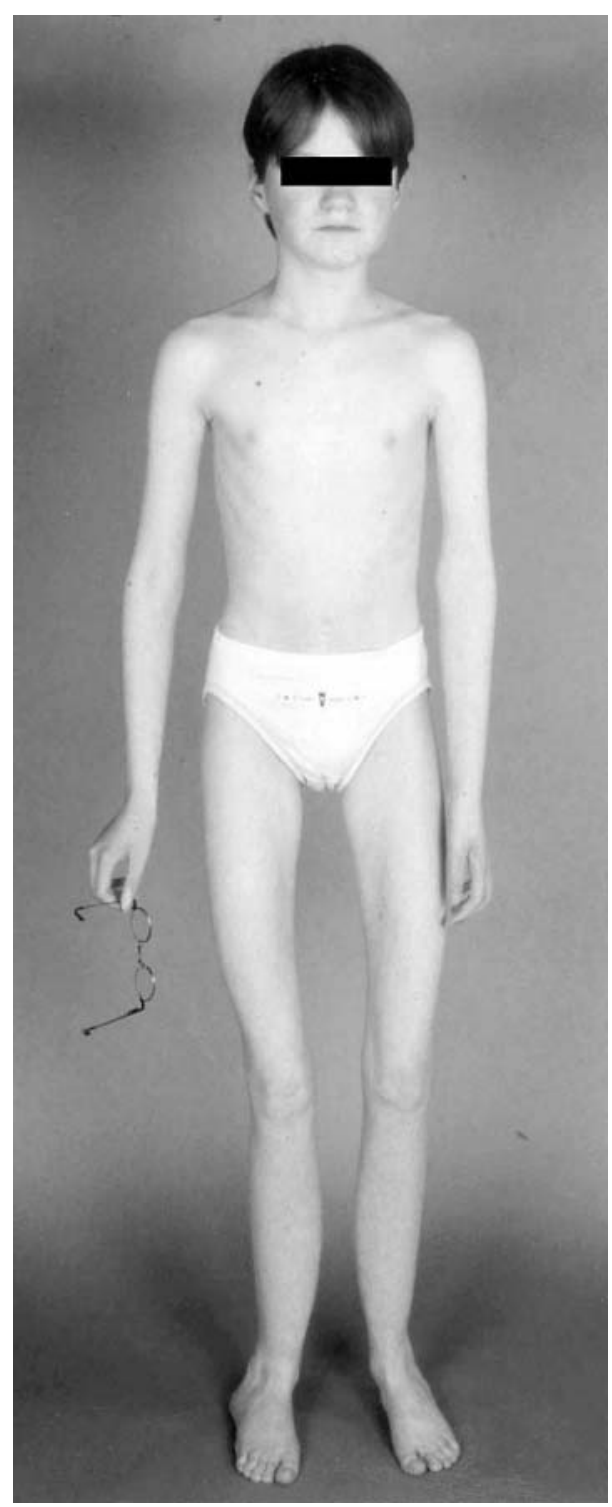

Figure 4 Clinical picture of the patient from family 14 at the age of 15. Note the absence of subcutaneous fat (weight $27 \mathrm{~kg}$ ), muscle hypotrophy, and valgus deformity of the knees and feet. Muscle weakness restricts her maximum walking distance to 20 to $50 \mathrm{~m}$. Secondary sex characteristics (breast development, menstruation) were delayed. Written permission of the patient for reproduction of this photograph was obtained.

possible explanation is the presence of modifier genes that modulate the outcome of the principal mutation (see above). However, in our opinion this is insufficient to account for the absence of symptoms during embryonic development, in which TGF $\beta 1$ is shown to play a crucial role, ${ }^{29-31}$ or in tissues like heart, pancreas, kidney, lung, and skin, where TGF $\beta 1$ is highly expressed during adult life. ${ }^{32} 33$ We propose the following hypothesis. TGF $\beta 1$ is post-translationally processed to a non-covalent small latent complex of the mature peptide and latency associated peptide. In most tissues, this complex covalently associates with a latency associated TGF $\beta$ binding protein to form a high molecular weight latent complex (large latent complex) that is directed for storage in the extracellular matrix. ${ }^{34}$ However, bone forms an exception, as bone cells produce predominantly the small latent complex, ${ }^{35-}$ 37 a form suggested to represent a pool of readily available TGF $\beta 1$-necessary in an environment where TGF $\beta 1$ plays

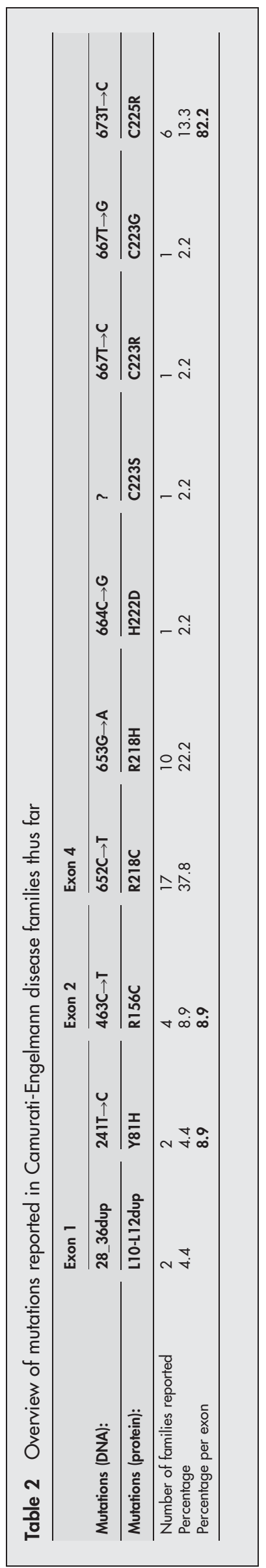




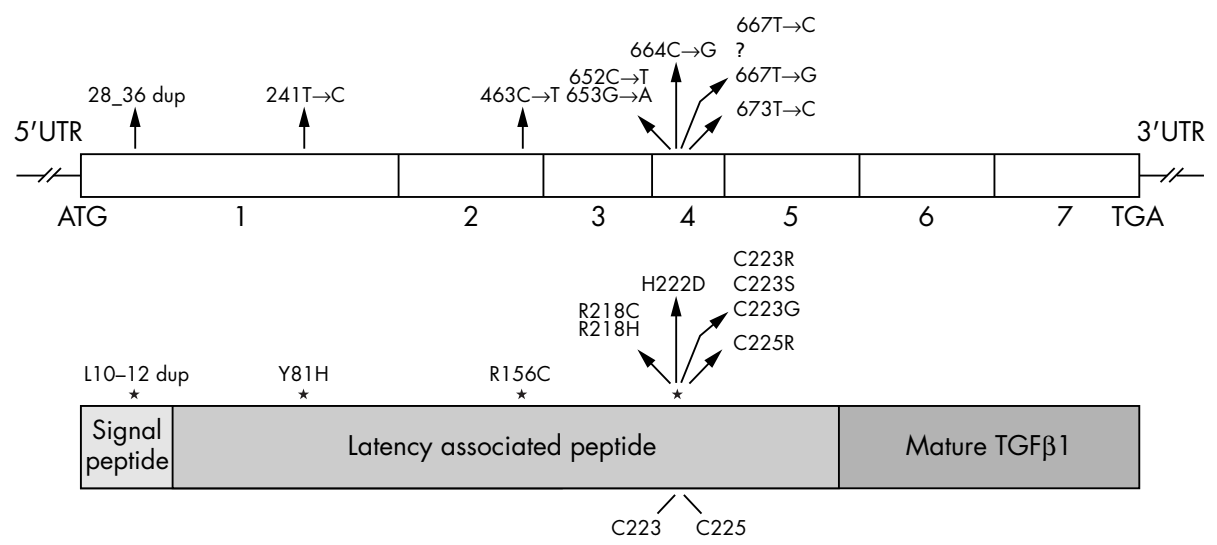

Figure 5 Position of Camurati-Engelmann disease (CED) mutations identified in TGF $\beta 1$ at DNA and protein level. Numbering of the mutations starts from the ATG start codon. Numbers indicate the TGFB1 exons. TGF, transforming growth factor.

such an important role throughout life. ${ }^{37}$ We raise the possibility that the capacity of a mutation to alter the structure of the latent complex depends on the presence of the latency associated TGF $\beta$ binding protein. Following this hypothesis, the conformational changes needed for premature activation of the mature peptide are quenched in the large latent complex. However, when secreted as the small latent complex, the latency associated peptide alters its conformation under the influence of the mutation, releasing some of the mature peptide or at least facilitating its activation. Experiments are under way to confirm or reject this hypothesis.

\section{TREATMENT}

\section{Drug treatment}

Glucocorticosteroids are anti-inflammatory and immunosuppressive agents. In bone, they exert the unfavourable side effect of decreasing bone density, first by increasing the apoptosis rate of osteoblasts and osteocytes while suppressing osteoblast proliferation, differentiation, and bone matrix synthesis $^{38}{ }^{39}$; second, by enhancing proliferation and differentiation of osteoclast precursors ${ }^{40}{ }^{41}$; and third, by decreasing intestinal calcium absorption. ${ }^{42}$ In CED patients, this "side effect" is turned into an advantage: glucocorticoids are applied to counteract the increased bone formation. Moreover, they exert a direct effect on TGF $\beta$ expression, activation, and signalling, although the exact mechanism needs further clarification. On the one hand, glucocorticoids are seen to stimulate TGF $\beta$ expression ${ }^{43}$ and increase latent TGF $\beta$ activation, ${ }^{44}$ which would imply that they could have adverse effects in CED patients, who show TGF $\beta 1$ overactivity. On the other hand, they have been found to induce a shift of TGF $\beta$ binding from the signalling-capable receptor to the non-signalling receptor, ${ }^{45-47}$ thereby downregulating signalling. Moreover, the glucocorticoid dexamethasone has been shown to interfere more downstream in the signalling pathway, thereby inhibiting TGF $\beta$ induced transcription of target genes. ${ }^{48}$

Several reports have described successful treatment of CED patients with the glucocorticoid prednisolone. ${ }^{49-53}$ In all cases, there was an improvement in clinical symptoms such as pain and fatigue. Correction of radiographic abnormalities has been documented as well. Of our patient set, 12 patients from nine different families are being treated with prednisolone or related drugs (table 1). For seven of them, information on the effect of treatment was made available. Suffering from lower limb pain, one of the patients from family 1 received high prednisone doses over a two year period. One month treatment courses kept her pain-free for several months, but pain relapsed in the course of time. One of the affected children from family 2 was treated with prednisone for one year, starting on a dose of $30 \mathrm{mg} /$ day, which was lowered to $10 \mathrm{mg}$ every second day. Weight, appetite, and walking ability increased notably and he complained of skeletal pain much less. Treatment was discontinued because he developed aggressive behaviour which was thought to be related to prednisolone. Treatment of the two clinically affected patients from family 3 resulted in improved mobility and decreased bone pain. However, treatment had to be suspended as the patients became Cushingoid. The symptomatic patient from family 5 benefited from prednisolone treatment as pain and muscle weakness disappeared, while appetite and vigour increased. For the patients from family 11, low glucocorticoid doses helped to suppress pain. Although it is tempting to speculate that glucocorticoids improve bone pain by suppressing bone formation, the improvement in clinical symptoms to treatment can be very rapid and is therefore unlikely to be caused by the suppressive effect on osteoblast function.

Despite these positive reports, long term glucocorticoid treatment is not advisable, as unfavourable side effects can occur. For example long term prednisolone use in children will impair linear growth. ${ }^{54}$ Furthermore, spinal osteoporosis-as present in two patients from family 3-might be related to long term corticosteroid treatment, as spine bone mineral density (BMD) in two patients from family 4 who were not treated with glucocorticoids was increased. Thus it is important to define the minimum effective dose. A good starting dose is $1 \mathrm{mg} / \mathrm{kg} / \mathrm{day}$, but this can and should be lowered during long term treatment. Deflazacort, a derivative of prednisolone, was reported to have a comparable effect in improving clinical and radiological symptoms, but to have fewer adverse effects, and might therefore form a safer alternative..$^{55}$

The value of bisphosphonates in the treatment of CED is disputed. Besides the five patients described here (table 1), there are very few reports of treatment with these drugs. One report mentions a worsening of bone pain on treatment with pamidronate, ${ }^{51}$ while in another, a patient profited by treatment with the same drug. ${ }^{56}$ A patient from family 6 underwent a five week course of treatment with weekly pamidronate infusions without amelioration of her symptoms. Likewise, two patients from family 3 did not benefit from a three month course of intravenous pamidronate treatment. Etidronate treatment in another patient (family 4) even had an adverse effect, as it augmented serum alkaline phosphatase levels above normal. Taking into account that bisphosphonates are widely used as antiresorptive drugs in 
the treatment of osteoporosis-increasing BMD and lowering fracture risk ${ }^{57}$ - they do not seem likely to have promise for the treatment of CED.

The treatment of one of the patients with calcitonin (family 4) is the first report on the use of this drug in CED therapy. Besides functioning as an analgesic, capable of relieving bone pain, ${ }^{58}$ calcitonin is also known as a potent inhibitor of bone resorption, hence its application in osteoporosis and Paget's disease. ${ }^{59}$ Consequently, it is unlikely that this drug will be useful for treating CED, although recent in vivo findings point to an additional role of calcitonin as an inhibitor of bone formation..$^{60}$ Application in the patient described here was discontinued as no improvement was apparent.

Other drugs used include non-steroid anti-inflammatory drugs (NSAIDs) such as aspirin. Although these drugs can alleviate pain, they are not effective at improving bone changes.

\section{Surgery}

An alternative to drug treatment is surgery. Bone overgrowth in the diaphyses, with concomitant narrowing of the medullary canal and modelling defects, can be alleviated by reaming of the medullary canal ${ }^{6162}$ or osteotomy (this report; families 3 and 24). Orbital decompression to remove bone encroachment on the optic nerves has been used in one case (family 10). However, as the disorder is progressive the symptoms will recur in time.

\section{Gene therapy}

In the future, gene therapy might be considered as an additional way to cure CED patients. Based on their capacity for sequestering the mature peptide, decorin, biglycan, $\alpha_{2}$ macroglobulin, soluble $\beta$-glycan, $\alpha_{2}$-HS glycoprotein/fetuin, anti-TGF $\beta$ monoclonal antibodies, or a soluble inactive type II receptor could be considered as possible drugs. ${ }^{63-66}$ Alternatively, inhibitors of downstream signalling molecules could be used. In all cases, it should be taken into account that TGF $\beta 1$ is implicated in a myriad of functions in the body, increasing the risk of unwanted side effects upon systemic administration of such a "quencher". Consequently, local application, confined to bone and muscle tissue, would be is preferable.

\section{DIAGNOSIS AND GENETIC COUNSELLING}

As clinical and radiological variability is extensive, molecular analysis can provide an additional resource for making a correct diagnosis. Family 5 presents a good example of the complementary nature of the clinical, radiological, and molecular findings. In a previous publication on this family, dating from 1994, the mother and maternal grandfather of a severely affected girl had been diagnosed with CED ${ }^{67}$ The mother did not show any radiological abnormalities, but scintigraphy demonstrated a focus of increased tracer uptake at the base of the skull. The grandfather was found to have marked fusiform enlargement and cortical thickening along the medial borders of the long bones, despite being symptomfree. Linkage analysis in the $19 \mathrm{q} 13$ region-previously defined as containing the CED gene ${ }^{12}$-excluded this locus. Although this could point to genetic heterogeneity, mutation analysis of TGFBI showed a Y81H missense mutation in the girl. The presence of the same mutation in family 6 confirmed this to be the disease causing mutation. The absence of the mutation in the mother of the girl and in other family members at the maternal side suggested that this was a de novo mutation. Alternatively, the mutation could be segregating in the paternal branch of the pedigree. Mutation analysis showed that the latter was the case, as the mutation was detected in the girl's father and paternal grandmother. Radiographic analyses of both individuals showed no signs of the disorder (though scintigraphy was not done). Although radiographs of the maternal grandfather were thought diagnostic of CED, bone scintigrams were considered normal. Unfortunately, no additional data on this individual were made available for further diagnosis. Furthermore, increased tracer uptake at the skull base, as seen in the mother, is a common phenomenon in the normal population and cannot be used as a diagnostic marker of CED. This example shows that a combination of clinical, radiological, scintigraphic, and molecular data may be mandatory for a definitive diagnosis of this disorder.

Interestingly, four of the five patients with radiological non-penetrance belong to the two families (families 5 and 6) carrying the $\mathrm{Y} 81 \mathrm{H}$ mutation. On comparison, it appears that the disease has a significantly lower penetrance in patients with the $\mathrm{Y} 81 \mathrm{H}$ variant. Of nine patients with the $\mathrm{Y} 81 \mathrm{H}$ mutation, only five $(56 \%)$ show signs of the disorder. On the other hand, the genotype is penetrant in 77 of 78 patients with a mutation different from the Y81H variant (99\%) $(\mathrm{p}<0.02)$. Although this could imply that the $\mathrm{Y} 81 \mathrm{H}$ variant is not the disease causing mutation, earlier functional experiments provided evidence to the contrary. Overexpression of the mutant protein in a cell culture system showed that the protein is less efficiently secreted than the wild-type protein, but far more capable of initiating the TGF $\beta$ signalling pathway. ${ }^{17}$

The extreme phenotypic variability of the disorder and occasional lack of penetrance render genetic counselling problematic, in particular dealing with the issue of prenatal diagnosis. A healthy carrier can give birth to a severely affected child. On the other hand, a severe affection status of the parent does not necessarily imply a negative disease course in the child. In the most severely affected patients, a normal way of life becomes difficult, as they are in constant pain and likely to be bedridden. As there is no possibility of predicting the disease outcome, even on the basis of the nature of the mutation, abortion upon prenatal testing can be contemplated. To our knowledge, only one affected parent from our series of patients considered prenatal diagnosis and obtained it following an in depth discussion with a genetic counsellor.

In conclusion, this survey of a large collection of families suffering from this rare bone disorder will aid the definition of the full spectrum and frequency of the various CED phenotypes, and may be of assistance to clinicians for both diagnosis and treatment.

\section{ACKNOWLEDGEMENTS}

This study is supported by the Fund for Scientific Research Flanders with a research project (G.0404.00), by an Interuniversity Attraction Poles programme P5/19 of the Belgian Federal Science Policy Office grant, and by a EU FP6 grant (Anabonos; LSHM-CT-2003-503020) to WVH. KJ is a postdoctoral researcher of the Fund for Scientific Research Flanders.

\footnotetext{
Authors' affiliations

K Janssens, W Van Hul, Department of Medical Genetics, University of Antwerp, Antwerp, Belgium

F Vanhoenacker, Department of Radiology, University Hospital Antwerp M Bonduelle, Department of Medical Genetics, University Hospital of Brussels, Brussels, Belgium

L Verbruggen, Department of Rheumatology, University Hospital of Brussels

L Van Maldergem, Centre of Human Genetics, Institute of Pathology and Genetics, Loverval, Belgium

S Ralston, Rheumatic Diseases Unit, University of Edinburgh, Edinburgh, UK

N Guañabens, Department of Rheumatology, Hospital Clinic, Barcelona, Spain

N Migone, Department of Genetics, Biology and Biochemistry, University of Torino, Torino, Italy
} 
S Wientroub, Department of Paediatric Orthopaedics, Tel Aviv University, Tel Aviv, Israel

M T Divizia, Department of Molecular Genetics, Gaslini Institute, Genova Quarto, Italy

C Bergmann, Institute of Human Genetics, Aachen University, Aachen, Germany

C Bennett, Clinical Genetics, St James's University Hospital, Leeds, UK S Simsek, Endocrinology/Diabetes Centre, VU Medical Centre,

Amsterdam, the Netherlands

S Melançon, Procrea, Mount-Royal, Canada

T Cundy, Department of Medicine, University of Auckland, Auckland, New Zealand

Conflicts of interest: none declared

\section{REFERENCES}

1 Cockayne EA. Case for diagnosis. Proc R Soc Med 1920;13:132-6.

2 Camurati M. Di un raro caso di osteite simmetrica ereditaria degli arti inferiori. Chirurgia degli Organi di Movimento 1922;6:662-5.

3 Engelmann G. Ein fall von ostheopathia hyperostotica (sclerotisans) multiplex infantilis. Forschritte auf dem Gebiete der Röntgenstrahlen und der Nuklearmedizin 1929;39:1101-6.

4 Neuhauser EB, Schwachman H, Wittenborg M, Cohen J. Progressive diaphyseal dysplasia. Radiology 1948;51:11-22.

5 Sparkes RS, Graham CB. Camurati-Engelmann disease. Genetics and clinical manifestations with a review of the literature. J Med Genet 1972;9:73-85.

6 Crisp AJ, Brenton DP. Engelmann's disease of bone - a systemic disorder? Ann Rheum Dis 1982;41:183-8.

7 Hernandez MV, Peris P, Guanabens N, Alvarez L, Monegal A, Pons F, Ponce A, Munoz-Gomez J. Biochemical markers of bone turnover in Camurati-Engelmann disease: a report on four cases in one family. Calcif Tissue Int 1997;61:48-51.

8 Smith R, Walton RJ, Corner BD, Gordon IR. Clinical and biochemical studies in Engelmann's disease (progressive diaphyseal dysplasia). QJM 1977;46:273-94.

9 Makita Y, Nishimura G, Ikegawa S, Ishii T, Ito Y, Okuno A. Intrafamilial phenotypic variability in Engelmann disease (ED): are ED and Ribbing disease the same entity? Am J Med Genet 2000;91:153-6.

10 Campos-Xavier B, Saraiva JM, Savarirayan R, Verloes A, Feingold J, Faivre L, Munnich A, Le Merrer M, Cormier-Daire V. Phenotypic variability at the TGFbetal locus in Camurati-Engelmann disease. Hum Genet 2001;109:653-8.

11 Wallace SE, Lachman RS, Mekikian PB, Bui KK, Wilcox WR. Marked phenotypic variability in progressive diaphyseal dysplasia (CamuratiEngelmann disease): report of a four-generation pedigree, identification of a mutation in TGFB1, and review. Am J Med Genet 2004;129A:235-47.

12 Janssens K, Gershoni-Baruch R, Van Hul E, Brik R, Guanabens N, Migone N, Verbruggen LA, Ralston SH, Bonduelle M, Van Maldergem L, Vanhoenacker F, Van Hul W. Localisation of the gene causing diaphyseal dysplasia CamuratiEngelmann to chromosome 19q13. J Med Genet 2000;37:245-9.

13 Janssens K, Gershoni-Baruch R, Guanabens N, Migone N, Ralston S, Bonduelle M, Lissens W, Van Maldergem L, Vanhoenacker F, Verbruggen L, $\mathrm{Van} \mathrm{Hul}$ W. Mutations in the gene encoding the latency-associated peptide of TGF-beta 1 cause Camurati-Engelmann disease. Nat Genet 2000;26:273-5.

14 Kinoshita A, Saito T, Tomita H, Makita Y, Yoshida K, Ghadami M, Yamada K, Kondo S, Ikegawa S, Nishimura G, Fukushima Y, Nakagomi T, Saito H, Sugimoto T, Kamegaya M, Hisa K, Murray JC, Taniguchi N, Niikawa N, Yoshiura K. Domain-specific mutations in TGFB1 result in CamuratiEngelmann disease. Nat Genet 2000;26:19-20.

15 Hecht JT, Blanton SH, Broussard S, Scott A, Rhoades Hall C, Milunsky JM. Evidence for locus heterogeneity in the Camurati-Engelmann (DPD1) syndrome. Clin Genet 2001;59:198-200.

16 Mumm SR, Obrecht S, Podgornik MN, Whyte MP. Camurati-Engelmann Disease: New mutations in the latency-associated peptide of the transforming growth factor beta-1 gene. J Bone Miner Res 2001;16(suppl 1):S223.

17 Janssens K, ten Dijke P, Ralston SH, Bergmann C, Van Hul W. Transforming growth factor-beta 1 mutations in Camurati-Engelmann disease lead to increased signaling by altering either activation or secretion of the mutant protein. J Biol Chem 2003;278:7718-24.

18 Kinoshita A, Fukumaki Y, Shirahama S, Miyahara A, Nishimura G, Haga N, Namba A, Ueda H, Hayashi H, Ikegawa S, Seidel J, Niikawa N, Yoshiura K. TGFB1 mutations in four new families with Camurati-Engelmann disease: confirmation of independently arising LAP-domain-specific mutations. Am J Med Genet 2004;127A: 104-7.

19 Saraiva JM. Progressive diaphyseal dysplasia: a three-generation family with markedly variable expressivity. Am J Med Genet 1997;71:348-52.

20 Simsek S, Janssens K, Kwee ML, Van Hul W, Veenstra J, Netelenbos JC. Camurati-Engelmann Disease (progressive diaphyseal dysplasia) in a Moroccan family. Osteoporos Int 2005;16:1167-70.

21 Saito T, Kinoshita A, Yoshiura K, Makita Y, Wakui K, Honke K, Niikawa N, Taniguchi N. Domain-specific mutations of a transforming growth factor (TGF)-beta 1 latency-associated peptide cause Camurati-Engelmann disease because of the formation of a constitutively active form of TGF-beta 1. J Biol Chem $2001 ; 276: 11469-72$

22 Janssens K, ten Dijke P, Janssens S, Van Hul W. Transforming growth factorbetal to the bone. Endocr Rev 2005;26:743-74.
23 Massague J, Cheifetz S, Endo T, Nadal-Ginard B. Type beta transforming growth factor is an inhibitor of myogenic differentiation. Proc Natl Acad Sci USA 1986;83:8206-10

24 Zhu S, Goldschmidt-Clermont PJ, Dong C. Transforming growth factor-betainduced inhibition of myogenesis is mediated through Smad pathway and is modulated by microtubule dynamic stability. Circ Res 2004;94:617-25.

25 Ignotz RA, Massague J. Type beta transforming growth factor controls the adipogenic differentiation of 3T3 fibroblasts. Proc Natl Acad Sci USA 1985:82:8530-4.

26 Choy L, Derynck R. Transforming growth factor-beta inhibits adipocyte differentiation by Smad3 interacting with CCAAT/enhancer-binding protein (C/EBP) and repressing C/EBP transactivation function. J Biol Chem 2003;278:9609-19.

27 Shin SM, Kim K, Kim JK, Yoon SR, Choi I, Yang Y. Dexamethasone reverses TGF-beta-mediated inhibition of primary rat preadipocyte differentiation. FEBS Lett 2003;543:25-30.

28 Roberts $A B$, Sporn $M B$. The transforming growth factor-betas. In: Sporn MB, Roberts $A B$, eds. Peptide growth factors and their receptors. Heidelberg: Springer-Verlag, 1990:419-72.

29 Heine U, Munoz EF, Flanders KC, Ellingsworth LR, Lam HY, Thompson NL, Roberts $A B$, Sporn MB. Role of transforming growth factor-beta in the development of the mouse embryo. J Cell Biol 1987;105:2861-76.

30 Lehnert SA, Akhurst RJ. Embryonic expression pattern of TGF beta type-1 RNA suggests both paracrine and autocrine mechanisms of action. Development 1988;104:263-73

31 Pelton RW, Saxena B, Jones M, Moses HL, Gold LI. Immunohistochemical localization of TGF beta 1, TGF beta 2, and TGF beta 3 in the mouse embryo: expression patterns suggest multiple roles during embryonic development. J Cell Biol 1991;115:1091-105.

32 Miller DA, Lee A, Matsui Y, Chen EY, Moses HL, Derynck R. Complementary DNA cloning of the murine transforming growth factor-beta 3 (TGF beta 3 ) precursor and the comparative expression of TGF beta 3 and TGF beta 1 messenger RNA in murine embryos and adult tissues. Mol Endocrinol 1989;3:1926-34

33 Thompson NL, Flanders KC, Smith JM, Ellingsworth LR, Roberts AB, Sporn MB. Expression of transforming growth factor-beta 1 in specific cells and tissues of adult and neonatal mice. J Cell Biol 1989;108(2):661-9.

34 Oklü R, Hesketh R. The latent transforming growth factor beta binding protein (LTBP) family. Biochem J 2000;352 Pt 3:601-10.

35 Pedrozo HA, Schwartz Z, Mokeyev T, Ornoy A, Xin-Sheng W, Bonewald LF, Dean DD, Boyan BD. Vitamin D3 metabolites regulate LTBP1 and latent TGFbetal expression and latent TGF-betal incorporation in the extracellular matrix of chondrocytes. J Cell Biochem 1999:72:151-65.

36 Bonewald LF, Wakefield L, Oreffo RO, Escobedo A, Twardzik DR, Mundy GR. Latent forms of transforming growth factor-beta (TGF beta) derived from bone cultures: identification of a naturally occurring 100-kDa complex with similarity to recombinant latent TGF beta. Mol Endocrinol 1991;5:741-51.

37 Dallas SL, Park-Snyder S, Miyazono K, Twardzik D, Mundy GR, Bonewald LF. Characterization and autoregulation of latent transforming growth factor beta (TGF beta) complexes in osteoblast-like cell lines. Production of a latent complex lacking the latent TGF beta-binding protein. J Biol Chem 1994;269:6815-21.

38 Cooper MS, Hewison M, Stewart PM. Glucocorticoid activity, inactivity and the osteoblast. J Endocrinol 1999;163:159-64.

39 Weinstein RS, Jilka RL, Parfitt AM, Manolagas SC. Inhibition of osteoblastogenesis and promotion of apoptosis of osteoblasts and osteocytes by glucocorticoids. Potential mechanisms of their deleterious effects on bone. J Clin Invest 1998;102:274-82.

40 Takuma A, Kaneda T, Sato T, Ninomiya S, Kumegawa M, Hakeda Y. Dexamethasone enhances osteoclast formation synergistically with transforming growth factor-beta by stimulating the priming of osteoclast progenitors for differentiation into osteoclasts. J Biol Chem 2003;278:44667-74.

41 Hirayama T, Sabokbar A, Athanasou NA. Effect of corticosteroids on human osteoclast formation and activity. J Endocrinol 2002;175:155-63.

42 Gennari C. Differential effect of glucocorticoids on calcium absorption and bone mass. Br J Rheumatol 1993;32(suppl 2):11-14.

43 Almawi WY, Abou Jaoude MM, Li XC. Transcriptional and posttranscriptional mechanisms of glucocorticoid antiproliferative effects. Hematol Oncol 2002;20:17-32.

44 Oursler MJ, Riggs BL, Spelsberg TC. Glucocorticoid-induced activation of latent transforming growth factor-beta by normal human osteoblast-like cells. Endocrinology 1993;133:2187-96.

45 Centrella M, McCarthy TL, Canalis E. Glucocorticoid regulation of transforming growth factor beta 1 activity and binding in osteoblast-enriched cultures from fetal rat bone. Mol Cell Biol 1991;11:4490-6.

46 Chang DJ, Ji C, Kim KK, Casinghino S, McCarthy TL, Centrella M. Reduction in transforming growth factor beta receptor I expression and transcription factor CBFal on bone cells by glucocorticoid. J Biol Chem 1998;273:4892-6.

47 Nakayama H, Ichikawa F, Andres JL, Massague J, Noda M. Dexamethasone enhancement of betaglycan (TGF-beta type III receptor) gene expression in osteoblast-like cells. Exp Cell Res 1994;211:301-6.

48 Song CZ, Tian X, Gelehrter TD. Glucocorticoid receptor inhibits transforming growth factor-beta signaling by directly targeting the transcriptional activation function of Smad3. Proc Natl Acad Sci USA 1999;96:11776-81.

49 Bourantas K, Tsiara S, Drosos AA. Successful treatment with corticosteroid in a patient with progressive diaphyseal dysplasia. Clin Rheumatol 1995; 14:485-6.

50 Heymans O, Gebhart M, Alexiou J, Sokolow Y. Camurati-Engelmann disease. Effects of corticosteroids. Acta Clin Belg 1998;53:189-92. 
51 Inaoka T, Shuke N, Sato J, Ishikawa Y, Takahashi K, Aburano T, Makita Y. Scintigraphic evaluation of pamidronate and corticosteroid therapy in a patient with progressive diaphyseal dysplasia (Camurati-Engelmann disease) Clin Nucl Med 2001;26:680-2.

52 Naveh Y, Alon U, Kaftori JK, Berant M. Progressive diaphyseal dysplasia: evaluation of corticosteroid therapy. Pediatrics 1985;75:321-3.

53 Verbruggen LA, Bossuyt A, Schrever R, Somers G. Clinical and scintigraphic evaluation of corticosteroid treatment in a case of progressive diaphyseal dysplasia. J Rheumatol 1985;12:809-13.

54 Emma F, Sesto A, Rizzoni G. Long-term linear growth of children with severe steroid-responsive nephrotic syndrome. Pediatr Nephrol 2003;18:783-8.

55 Bas F, Darendeliler F, Petorak I, Sadikoglu B, Bilir A, Bundak R, Saka N, Gunoz H. Deflazacort treatment in progressive diaphyseal dysplasia (Camurati-Engelmann disease). J Paediatr Child Health 1999;35:401-5.

56 Cherie-Ligniere G, Santalena G, Parafioriti A. Pamidronate in the treatment of progressive diaphyseal dysplasia (Camurati-Engelmann disease). Clin Exp Rheumatol 1999;17:264

57 Watts NB. Bisphosphonate treatment of osteoporosis. Clin Geriatr Med 2003;19:395-414.

58 Silverman SL, Azria M. The analgesic role of calcitonin following osteoporotic fracture. Osteoporos Int 2002;13:858-67.

59 Zaidi M, Inzerillo AM, Moonga BS, Bevis PJ, Huang CL. Forty years of calcitonin - where are we now? A tribute to the work of lain Macintyre, FRS Bone 2002;30:655-63.
60 Hoff AO, Catala-Lehnen P, Thomas PM, Priemel M, Rueger JM, Nasonkin I Bradley A, Hughes MR, Ordonez N, Cote GJ, Amling M, Gagel RF. Increased bone mass is an unexpected phenotype associated with deletion of the calcitonin gene. J Clin Invest 2002;110:1849-57.

61 Lazzarone C, Cartesegna M, Crova M, Calorio D. Progressive diaphyseal dysplasia: Camurati-Engelmann's disease. Ital J Orthop Traumatol 1983;9:109-14.

62 Raffaelli P, Ronzini MF. Camurati-Engelmann's disease. A case report. Ital J Orthop Traumatol 1988;14:267-71.

63 Yamaguchi Y, Mann DM, Ruoslahti E. Negative regulation of transforming growth factor-beta by the proteoglycan decorin. Nature 1990;346:281-4.

64 O'Connor-McCourt MD, Wakefield LM. Latent transforming growth factorbeta in serum. A specific complex with alpha 2-macroglobulin. J Biol Chem 1987;262:14090-9.

65 Lopez-Casillas F, Payne HM, Andres JL, Massague J. Betaglycan can act as a dual modulator of TGF-beta access to signaling receptors: mapping of ligand binding and GAG attachment sites. J Cell Biol 1994; 124:557-68.

66 Szweras M, Liu D, Partridge EA, Pawling J, Sukhu B, Clokie C, JahnenDechent W, Tenenbaum HC, Swallow CJ, Grynpas MD, Dennis JW. Alpha 2HS glycoprotein/fetuin, a transforming growth factor-beta/bone morphogenetic protein antagonist, regulates postnatal bone growth and remodeling. J Biol Chem 2002;277:19991-7.

67 Clybouw C, Desmyttere S, Bonduelle M, Piepsz A. Camurati-Engelmann disease: contribution of bone scintigraphy to genetic counseling. Genet Couns 1994;5: 195-8.

\section{Get published within days of acceptance with JMG}

We are delighted to announce that the Journal of Medical Genetics launched a "publish ahead of print" programme in March 2005. Selected papers are fast tracked and published online months before they appear in the print journal.

Papers of more significance to the international ophthalmology community are published within days of acceptance. The first published article is the raw accepted manuscript; edited and typeset versions are also published as soon as they are available.

In addition to being available on JMG Online, the publish ahead of print articles are searchable through PubMed/Medline - establishing primacy for your work. They are linked from the JMG Online home page.

The JMG's publish ahead of print programme is unique among the major clinical genetics journals - to take advantage of this service submit your papers to Journal of Medical Genetics using our online submission and review system Bench>Press (http://submit-jmg.bmijournals. com). For further information contact JMG@bmigroup.com. 